\title{
Geothermal response of a geothermal system for energy piles in a typical Brazilian tropical soil
}

\author{
Roberto Pimentel de Sousa Júnior ${ }^{1,}{ }^{*}$, Renato Pinto Cunha ${ }^{1}$, and Rideci de Jesus da Costa Farias ${ }^{1}$ \\ ${ }^{1}$ UnB, University of Brasília, Brasília, Brazil
}

\begin{abstract}
For a long time ago energy piles systems have been used for heating and/ or cooling purposes. The proposal of a conditioning system for closed environments that is economical and sustainable has drawn attention in Brazil, a country that is experiencing energy difficulties and have a high demand for thermal conditioning in most of its territory. Different configurations of foundation blocks were simulated, and an extensive geological-geotechnical survey of the soil chosen as representative of the Federal District, allowed the calculation of the thermal parameters of this soil. With these parameters the next step were the numerical simulations, the aim of this paper, which varied the foundations with the number of pile caps, piles diameter and turns in the pipe, seeking the best configuration for the region studied. As a result of this work, it was concluded that for blocks with pile diameters of 30 and $40 \mathrm{~cm}$, the ideal is the use of only two turns in the pipes for blocks with 4 or more piles, while for piles of $60 \mathrm{~cm}$ three turns in the pipe generates a maximum exchange of heat. It is also concluded that the soil of the Federal District has a high potential for heat exchange.
\end{abstract}

\section{Introduction}

Brazil is a country of different climates: equatorial, semi-arid; tropical and $53.8 \%$ of its territory can be considered wet and hot, and $25.2 \%$ dry and hot, totaling $79 \%$ of the territory as a hot climate area [1], market potential for new modes of environment conditioning, as in the case of heat exchange piles.

Analysing the economic-industrial context, Brazil loses competitiveness due to the high value of its energy, which is on average $134 \%$ higher than the average of other BRIC countries. According [9], the exit to make Brazil more competitive is in the diversification of the energy matrix. Therefore, it is necessary to develop new technologies and sources of renewable energy, such as the case of surface geothermal energy using the foundation structures. This paper aims to discover how a typical soil from the Federal District of Brazil behaves in relation to the geothermal response of piles similar to the commercial ones of the region. This way, numerical methods are used to simulate blocks of piles typical of the practice of foundations engineering in the region and for this simulate various variables such as piles diameter, number of piles in the blocks, turns in the pipes immersed in the piles and soil parameters. Finally, from the results, recommendations are given for energy piles projects in the region.

\section{Materials and Methods}

\subsection{Brasília soil}

The soil used to make this study was the soil of the experimental field of the University of Brasília, more precisely in the Postgraduate in Geotechnics site. The criterion that led to the choice of location was due to the large number of works already developed in it, which facilitate the search of information about it. The University is located in Brasilia, more precisely in the North Wing $\left(15^{\circ} 45.955 \mathrm{~S}, 47^{\circ} 52.384^{\prime} \mathrm{W}\right)$.

This soil is composed of 3 layers. The first layer of clay sand ranging from 0 to $3.5 \mathrm{~m}$, the second is sandy clay and is between 3.5 and $8.5 \mathrm{~m}$, a transition horizon between $8.5 \mathrm{~m}$ and $10.0 \mathrm{~m}$ and finally from 10.0 to 12.0 $\mathrm{m}$ a silt. As presented in Fig. 1.

In order to obtain geotechnical data from the site, 4 drill holes were run on the same campus for further studies. In addition, a well with mechanized excavation was made in order to measure the soil temperature profile. Soil geotechnical profile characteristic of the UnB experimental campus is shown in Fig.2, and the Fig. 3 the minimum and maximum moisture content of the soil profile (unsaturated), so indicate the seasonal variation of water content of soil.

\footnotetext{
* Corresponding author: eng.robertopimentel@gmail.com
} 


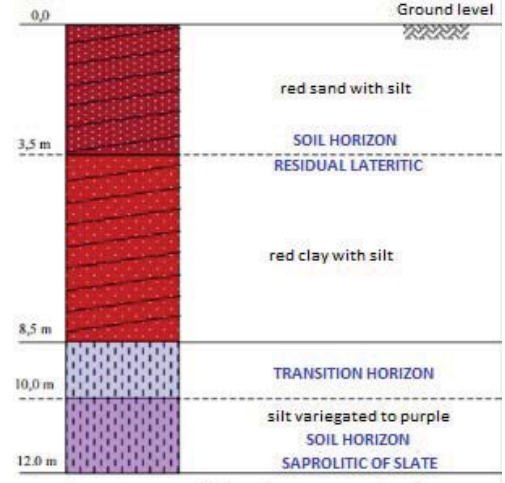

Fig. 1. Characteristic soil profile of UnB experimental field. Modified [7]

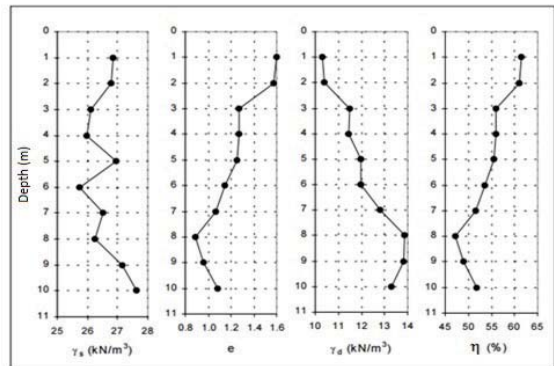

Fig. 2. Soil geotechnical profile characteristic of the UnB experimental campus [7]

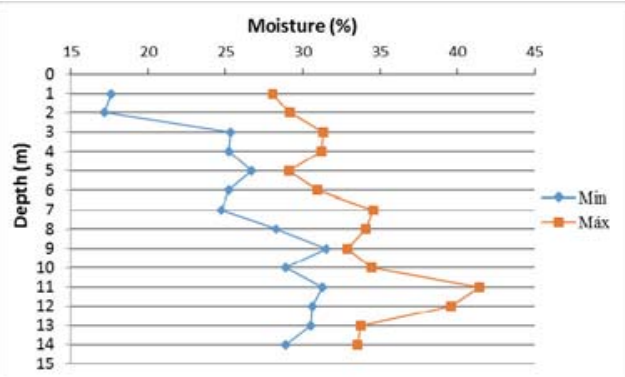

Fig. 3. Maximum and minimum values of moisture content per depth for the UnB experimental field (gravimetric water content)

By means of X-ray diffraction tests the study described mineralogically the soil profile of the experimental campus [2]. Fig. 4 presents the mineralogical profiles of the soil. In this, it is observed that the gibsite content starts high and decays until reaching $0 \%$ at 9 meters deep. The kaolinite, on the other hand, does the inverse process, varying between $30 \%$ and $40 \%$ for greater depths. The sum of the gibsite, kaolinite and ilite materials remain between $40 \%$ and $60 \%$ at all depth, while the sum of hematite and goethite remain between $10 \%$ and $15 \%$ throughout the entire profile.

To measure the tendency of soil temperature value along the depth, a mechanized excavation of the soil was carried out. Meter to meter with the aid of a thermometer the soil temperature was measured between days $03 / 12 / 16$ and $05 / 12 / 18$. For each meter, the highest and lowest temperature for the construction of the graph in Fig. 5 was used.
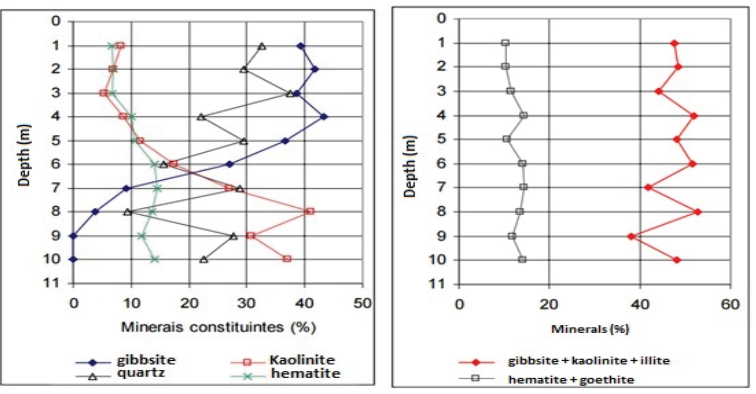

Fig. 4. Mineralogical profile of the soil characteristic of the UnB experimental campus [2]

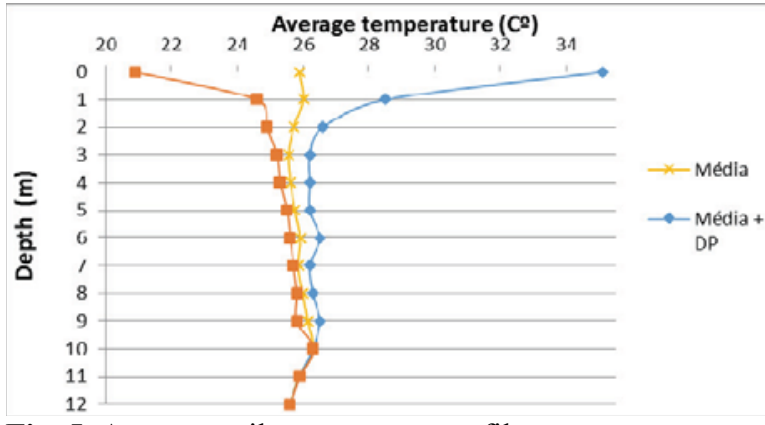

Fig. 5. Average soil temperature profile

\subsection{Group of piles}

In order to identify projects that were consistent with the practice of local foundations engineering, 16 commercial and local buildings projects in the city of Brasilia were used and from a study that identified the most important characteristics and arrived at the determination of the configurations to be simulated. See figure 6 .

Each of the blocks are composed of 4 parameters:

- Number of piles, which corresponds to the first column and can be $1,2,4,6$ or 9 piles;

- $\quad$ Pile diameter that can be of $0.3 \mathrm{~m}, 0.4 \mathrm{~m}$ and $0.6 \mathrm{~m}$;

- Pipe turns on piles that can be 1, 2 or 3 turns;

- Thermal parameters calculated with maximum or minimum humidity.

This means that any pile is identified only with its nomenclature, ex. B2-D03-2U-W +, block with 2 piles, $0.3 \mathrm{~m}$ piles diameter, 2 turns in the pipe and parameters of the soil with maximum humidity.

\subsection{Soil thermal parameters}

For the heat exchange calculations between the cuttings and the soil, the latter requires two thermal parameters that indicate its behavior: the thermal conductivity and the specific thermal capacity. For this research, we used semi-empirical equations to calculate these properties.

\subsubsection{Thermal Conductivity}

Thermal conductivity can be defined as the property that measures the transfer of energy or heat between 
molecules that make up the soil particles. For this research in particular two calculation methods were used, one for granular materials [3] and for fine materials [11].

- Cotê \& Konrad (2005) [3] for granular materials:

$$
\begin{aligned}
& K_{s}=\prod_{j} k_{m j}^{x j}, \text { where } \Sigma_{j} x j=1 \\
& K_{s a t}=k_{z}^{1-\gamma_{j}} 0.6^{\eta} \\
& K_{r}=\frac{\beta S_{T}}{1+(\beta-1) s_{r}} \\
& K_{d r y}=X 10^{-\eta n} \\
& K=\left(K_{s a t}-K_{d r y}\right) K_{r}+K_{d i y}
\end{aligned}
$$

$K_{m \text { - Thermal conductivity of the analysed soil minerals }}$ (W/m.K)

$\mathrm{Sr}$ - Degree of saturation (nondimensional)

$\eta$-porosity (nondimensional)

Ks - Thermal conductivity of soil-forming minerals (W/m.K)

Ksat - Saturated soil thermal conductivity (W/m.K)

$\mathrm{Kr}$ - Standard thermal conductivity

Kdry - Dry soil thermal conductivity

Table 1. Parameter values $\chi$ and $\mathrm{n}[3]$

\begin{tabular}{|c|c|c|}
\hline Type of soil & $\mathrm{X}$ & $\mathrm{n}$ \\
\hline $\begin{array}{c}\text { Gravels and } \\
\text { sands }\end{array}$ & 1.70 & 1.80 \\
\hline $\begin{array}{c}\text { Fine soils and } \\
\text { natural sands }\end{array}$ & 0.75 & 1.20 \\
\hline Organic & 0.30 & 0.87 \\
\hline
\end{tabular}

Table Error! No text of specified style in document.. Parameter values $\beta$ [3]

\begin{tabular}{|c|c|}
\hline Type of soil & $\beta$ \\
\hline $\begin{array}{c}\text { Gravels and thick } \\
\text { sands }\end{array}$ & 4.60 \\
\hline $\begin{array}{c}\text { Medium and fine } \\
\text { sands }\end{array}$ & 3.55 \\
\hline Silt and clay soils & 1.90 \\
\hline Fibrous organic soils & 0.60 \\
\hline
\end{tabular}

- The model of Lu et al. (2007) [11] for fine soils with low saturation:

The calculation process follows the same steps for calculation by the Cotê and Konrad model, only the $\mathrm{Kr}$ and Kdry equations to be replaced by 6 and 7 .

$$
\begin{array}{r}
K_{r}=\exp \left[\mu\left[1-5 r^{\mu-1.33} S r\right]\right] \\
K_{d r y}=-a \eta+b
\end{array}
$$

Empirical parameters $a$ and $b$, are 0.56 and 0.51 respectively for porosities between 0.2 and 0.6.

\subsubsection{Thermal Capacity}

The thermal capacity (C) describes the amount of heat supplied to a body related to the temperature variation it experiences. The specific thermal capacity $(\mathrm{Cp})$ is linked to the thermal capacity related to the mass unit of the material in question.

For this study was used the methodology of [8]. See equation 8 :

$c_{p-\text { soil thermal capacity }[\mathrm{J} / \mathrm{kg} . \mathrm{K}]}$

$\rho_{d-\text { dry soil density }\left[\mathrm{kg} / \mathrm{m}^{3}\right]}$

$\rho_{w}$ - water density $\left[\mathrm{kg} / \mathrm{m}^{3}\right]$

$\rho_{-}$bulk density of soil $\left[\mathrm{kg} / \mathrm{m}^{3}\right]$

$w_{-}$soil moisture (nondimensional)

$c_{\text {vw - volumetric capacity of the water }}$ $4.18 \times 106\left[\mathrm{~J} / \mathrm{m}^{3} \cdot \mathrm{K}\right]$

$$
c_{p}=\left(\frac{\rho_{a}}{\rho_{w} \rho}\right)(0.17+w) c_{w w}
$$

\subsection{Software}

COMSOL Multiphysics v5.2 Software is not a commonly used software for foundation engineering or heat exchange piles, but it has an immense range of phenomena that can be simulated, but it is necessary to incorporate other modules. In the case of heat exchange piles, two additional modules are required, one responsible for the hydraulic part and the other for the thermal part. The first one is called PipeFlow, while the second HeatTransfer.

\subsection{Characteristics of the study of thermos- hydraulic behaviour, initial conditions and contour of the model}

The investigation of the thermo-hydraulic behavior is done in all pile caps. For this, a system was simulated in the beginning of operation in soil not saturated thermally or hydraulically and from there the heat exchange for a determined time common to all simulations was measured.

Numerical simulations require initial and boundary conditions. The following are those used for the simulations performed:

a) Initial values of the model:

- The spacing between piles are 3 diameters center to center of piles; 
- Soil temperature: The initial soil temperature and the temperature profile was described in item 2.1;

- Piles temperature and pipe water: For this the same soil temperature was adopted, simulating start of operation with equalization between soil, piles and pipe water temperatures;

- Water flow in the pipeline: the same flow rate was adopted over the period to start;

- Pressure at the outlet of the pipe: atmospheric pressure was adopted, with a value of $102.100 \mathrm{~Pa}$;

- Time of the segment of analysis (Step Time): for this it was defined that the analyzes would be done every 1 hour or $(3600 \mathrm{~s})$;

- Total time of analysis: the end of the analysis occurs after 50 hours $(180.000 \mathrm{~s})$, exceeding the minimum for the TRT test established by [4], 48 hours $(178.200 \mathrm{~s})$

b) Contour conditions of the numerical model:

- Surface temperature: for this contour condition was used on 08/12/2016, day on which the soil temperature profile was measured and extrapolated to the next day to complete 50 hours of testing as shown in Fig. 6.

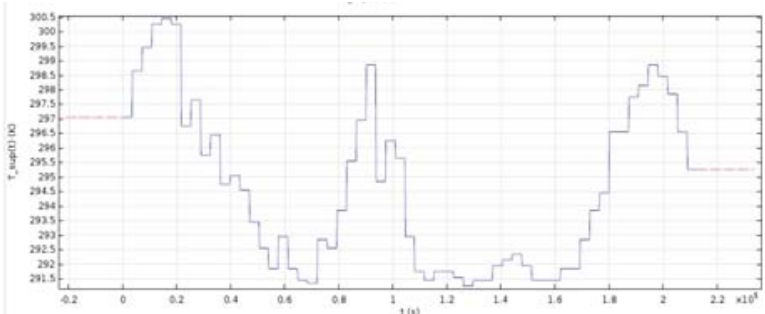

Fig. 6. Graph of the upper soil temperature [10]

- Constant temperature at depth: this condition at the lower boundary of the soil domain represents the constancy of temperature at a certain depth of the soil; It was considered $25^{\circ} \mathrm{C}(298.75 \mathrm{~K})$ and also considered it for the last 3 meters of soil domain where there was no more pipe immersed.

- Water temperature at the entrance of the pile: $35^{\circ} \mathrm{C}$ $(308.15 \mathrm{~K})$ was considered for this condition;

- Flow of the surrounding fluid in the pipes: this flow was considered constant throughout the period from start to finish and had a value $\left(4 * 10-4 \mathrm{~m}^{3} / \mathrm{s}\right)$.

\section{Results}

\subsection{Thermal properties of soil}

The first results that were extracted from the work are the thermal properties of the soil, which are input data for the program that simulates the heat exchange of the energy piles.

For the calculation of granular or fine materials, one of the considered parameters is the thermal conductivity of the minerals, described by equation 1 . In it the conductivity of each of the constituent minerals in the soil is taken into account and a geometric mean is made, with this the table 3 shows the thermal conductivity of the minerals found in the soil.

Table 3. Thermal Conductivity of Minerals

\begin{tabular}{|c|c|l|}
\hline Mineral & K $[\mathrm{W} / \mathrm{m} . \mathrm{K}]$ & \multicolumn{1}{|c|}{ Bibliographic } \\
\hline Gibbsite & 2.60 & Hokai, K.I.(1971) \\
\hline Kaolinite & 2.80 & $\begin{array}{l}\text { Midttomme, K., } \\
\text { et.al (1997) }\end{array}$ \\
\hline Quartz & 7.70 & Hokai, K.I.(1971) \\
\hline Hematite & 11.29 & Hokai, K.I.(1971) \\
\hline Goethita & 2.91 & Hokai, K.I.(1971) \\
\hline Anastasis & 6.53 & Wikipedia (2017) \\
\hline Rutile & 5.12 & Hokai, K.I.(1971) \\
\hline Illite & 1.80 & $\begin{array}{l}\text { Midttomme, K., } \\
\text { et.al (1997) }\end{array}$ \\
\hline
\end{tabular}

From 0 to $4 \mathrm{~m}$, the soil is granular in this way, the equations of [3] were used, while from 5 to $10 \mathrm{~m}$, the material is thin, which leads to the use of the method of [11]. In this way we arrive at the results expressed in Fig. 7.

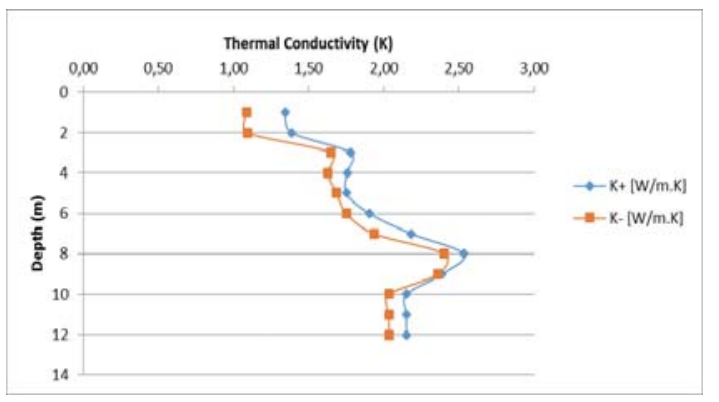

Fig. 7. Interval of calculated extreme values for thermal conductivity.

If it is the thermal capacity, the equations of [8] are used and the results are shown in Fig.8. For this method there is no distinction between the type of soil you are studying. 


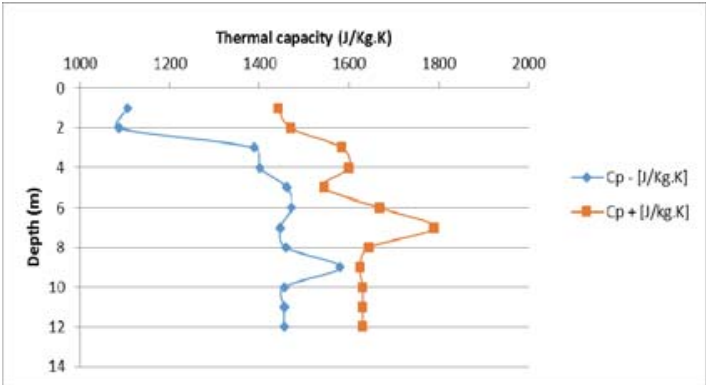

Fig. 8. Interval of calculated extreme values of thermal capacity.

\subsection{Numerical simulations}

The first results that were extracted from the work are the thermal Comsol Multiphysics software and any other thermal analysis software returns to the end of the simulation the difference between the input and output temperature, analyzes the propagation of the same along the studied material and the structure. However, in order to identify the efficiency of the system, we use units of energy measurements for this, in the case W. In this way, the efficiency is calculated by the following equation 9 .

$$
q_{L}=C_{W} \rho_{\mathrm{w}} q_{\text {entrada }}\left(\frac{T_{\text {inlat }}-T_{\text {outlat }}}{L_{g}}\right){ }_{[\mathrm{W} / \mathrm{m}]}
$$

Since $\mathrm{Cw}$ is the specific thermal capacity of water (4182 $[\mathrm{J} /(\mathrm{kg} * \mathrm{~K})]), \rho$ is the density of water $\left(106 \mathrm{~kg} / \mathrm{m}^{3}\right)$, with input mass flow $[\mathrm{Kg} / \mathrm{s}]$, and Tinlet e Toutlet fluid inlet and outlet temperatures in the tubing respectively and Le the length of the piles are shown.

At the end of the simulations, there are 2 results for each station, referring to the maximum and minimum that each pile could deliver of energy since the properties were calculated for maximum and minimum values according to the humidity. The results in Table 4 show the energy that the system delivers for each block configuration and the difference between input and output temperature reached by the pile. Finally, it has a figure with the averages of the energy delivered by the system. $\mathrm{W}+$ refers a result for the simulations using the maximum value of properties. In the same way, $\mathrm{W}$ - is the result using the minimum values.

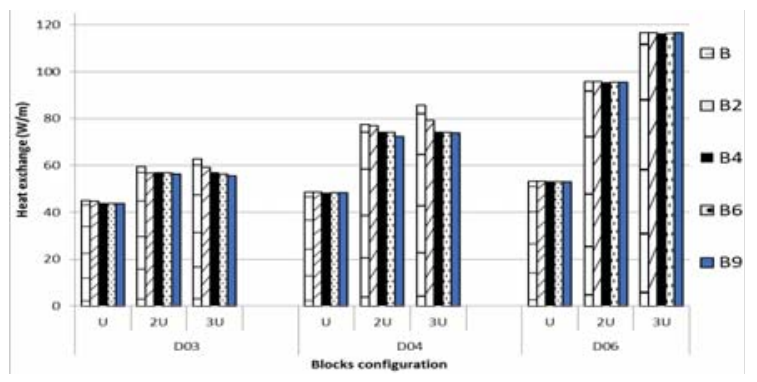

Fig. 9. General summary of the normalized heat exchange of all pile groups.
Table 4. Average heat exchange of the diameter with three turns in the pipe

\begin{tabular}{|l|l|l|l|l|l|l|}
\hline & $\begin{array}{l}\mathrm{W}+ \\
(\mathrm{W} / \mathrm{m})\end{array}$ & $\begin{array}{l}\mathrm{W}- \\
(\mathrm{W} / \mathrm{m})\end{array}$ & $\begin{array}{l}\text { Averag } \\
\mathrm{e} \\
(\mathrm{W} / \mathrm{m})\end{array}$ & $\begin{array}{l}\Delta \mathrm{T} \\
\mathrm{W}+ \\
\mathrm{K}\end{array}$ & $\begin{array}{l}\Delta \mathrm{T} \\
\mathrm{K}-\end{array}$ & $\begin{array}{l}\Delta \mathrm{T} \\
\text { Averag } \\
\mathrm{e} \mathrm{K}\end{array}$ \\
\hline $\begin{array}{l}\mathrm{D} 03 \\
-\mathrm{U}\end{array}$ & 45.33 & 43.29 & 44.31 & $\begin{array}{l}0.31 \\
0\end{array}$ & $\begin{array}{l}0.29 \\
7\end{array}$ & 0.304 \\
\hline $\begin{array}{l}\text { D04 } \\
-\mathrm{U}\end{array}$ & 49.36 & 47.61 & 48.48 & $\begin{array}{l}0.34 \\
0\end{array}$ & $\begin{array}{l}0.33 \\
0\end{array}$ & 0.335 \\
\hline $\begin{array}{l}\text { D06 } \\
-\mathrm{U}\end{array}$ & 53.85 & 52.51 & 53.18 & $\begin{array}{l}0.37 \\
0\end{array}$ & $\begin{array}{l}0.36 \\
0\end{array}$ & 0.365 \\
\hline $\begin{array}{l}\text { D03 } \\
-2 \mathrm{U}\end{array}$ & 59.01 & 55.52 & 57.26 & $\begin{array}{l}0.40 \\
5\end{array}$ & $\begin{array}{l}0.37 \\
7\end{array}$ & 0.391 \\
\hline $\begin{array}{l}\text { D04 } \\
-2 \mathrm{U}\end{array}$ & 76.85 & 73.23 & 75.04 & $\begin{array}{l}0.51 \\
8\end{array}$ & $\begin{array}{l}0.49 \\
6\end{array}$ & 0.507 \\
\hline $\begin{array}{l}\text { D06 } \\
-2 \mathrm{U}\end{array}$ & 97.14 & 93.99 & 95.56 & $\begin{array}{l}0.67 \\
0\end{array}$ & $\begin{array}{l}0.65 \\
0\end{array}$ & 0.660 \\
\hline $\begin{array}{l}\text { D03 } \\
-3 \mathrm{U}\end{array}$ & 60.38 & 56.06 & 58.22 & $\begin{array}{l}0.40 \\
6\end{array}$ & $\begin{array}{l}0.37 \\
6\end{array}$ & 0.391 \\
\hline $\begin{array}{l}\text { D04 } \\
-3 \mathrm{U}\end{array}$ & 79.95 & 75.14 & 77.55 & $\begin{array}{l}0.53 \\
3\end{array}$ & $\begin{array}{l}0.49 \\
8\end{array}$ & 0.516 \\
\hline $\begin{array}{l}\text { D06 } \\
-3 \mathrm{U}\end{array}$ & $\begin{array}{l}118.8 \\
6\end{array}$ & $\begin{array}{l}114.1 \\
3\end{array}$ & 116.49 & $\begin{array}{l}0.82 \\
0\end{array}$ & $\begin{array}{l}0.78 \\
2\end{array}$ & 0.801 \\
\hline
\end{tabular}

\section{Discussion}

After the data were processed, the results were analysed in several ways. In these simulations, the diameters of the piles, the number of piles in the foundation blocks, the number of turns of the pipes and the values of the thermal parameters of the soil were varied. As a comparison, the average heat exchange per meter per pile in the blocks was used. In addition to the efficiency of the blocks, the efficiency of the piles was also analyzed according to their position within the block. The following observations were made:

- The heat exchange of a pile is influenced by three geometric questions: the contact area between pile and the ground, the interference between the heat radiating from the pipe in the direction of descent and rise and the temperature radiated between the piles;

- Increasing the pile diameter increases the average heat exchange of the blocks. Because the pipes are close to the walls of the piles so increasing the diameter, the distance between the pipes will be bigger, then the area of contact between the piles and the ground too. Therefore, there is less interference between the irradiated temperature of 
the piping on one side and the other on the pole, providing a higher temperature gradient and consequently greater heat exchange at the pile;

- For equal blocks, the increase of the pile diameter and consequently of the spacing, maintains more constant the thermal efficiency of the piles, due to the smaller interference between the heat bulbs of the piles;

- Increasing the number of pipes inside a pile increases the interference between the miniature temperature bulbs, decreasing the temperature gradient and consequently the loss of heat and efficiency;

- As the piles diameter is increased by keeping the relative spacing, the difference in thermal efficiency within the blocks decreases;

- Piles with a diameter of $60 \mathrm{~cm}$, support the installation of 3 turns without significant loss of efficiency;

- For piles with a diameter of $60 \mathrm{~cm}$, the efficiency increases considerably with increasing from one to two turns, but does not increase in the same proportion when from two to three turns;

- Piles with $30 \mathrm{~cm}$ or $40 \mathrm{~cm}$ in diameter experience a considerable increase in heat exchange only when the number of turns of the pipe increases from one to two turns, the addition of the third does not generate expressive growth for blocks with 4 piles or more. This fact is explained by the increase in thermal interaction inside and outside the piles.

- For smaller diameters, the higher the number of turns, the greater the loss of efficiency between piles in relation to their position. This fact is due to the increase of the radius of heat, which generates greater interaction between the bulbs of the different piles.

- For diameters of $30 \mathrm{~cm}$ and $40 \mathrm{~cm}$, when the values of the thermal properties decrease due to the variation of humidity, the heat exchange falls, but the interaction between the piles is bigger, fact that generates greater efficiency decays of the blocks and piles. This apparently occurs because of two main thermal properties decrease with the soil moisture decline (thermal conductivity $(\mathrm{K})$ and specific thermal capacity $(\mathrm{Cp}))$.

\section{Conclusions}

Based on the analyses in this paper, in a project in which the piles diameter is an immutable factor, it is recommended for the following diameters:

- $\quad 30 \mathrm{~cm}$ : for blocks with 1 and 2 piles three turns in tubing and blocks with more piles only two turns are recommended.

- $40 \mathrm{~cm}$ : same consideration of the cuttings of $30 \mathrm{~cm}$.

- $60 \mathrm{~cm}$ : use for all blocks 3 turns, it is believed that 4 or more turns could generate greater heat exchange.
In the case of a project that requires the maximum thermal energy and the piles diameter is a changeable factor, it is recommended that among the diameters and pipes studied, use $60 \mathrm{~cm}$ diameter piles and three turns in the pipe. Finally, a very relevant factor that cannot be modified in design, soil moisture, has a direct influence on the exchange rates in general, independent of the configuration of the cuttings. When the humidity is higher, the rate of heat exchange increases, and when it is lower, that value drops considerably.

\section{References}

1. V. M. Alves, A. L. Schmid. Cooling and heating potential of underground soil according to depth. Energy and Buildings(90), 41-50 (2015)

2. M. N. Carvalho. Seminário da Disciplina Geotecnia dos Solos Tropicais,. Programa de Pós-Graduação em Geotecnia, Departamento de Engenharia Civil e Ambiental, Universidade de Brasília, Brasília, DF, 6 p. (1995)

3. J. Côté, J. M. Konrad. A generalized thermal conductivity model for soils and construction materials. Canadian Geotechnical Journal, 42(2), 443-458 (2005)

4. EUROCODE 7, TC 341 - Ground Investigation and testing, N 525 - Geothermal Testing Determination of Thermal Conductivity of Soil and Rock using a Borehole Heat Exchanger (2011)

5. KI-ITI Hokai. Thermal conductivity of rockforming minerals. Journal of Geophysical Research, 20(5,) 1278-1308 (1971)

6. K. Midttomme, E. Roaldset. AAGAARD, PThermal conductivity of selected claystones and mudstones from England. Clay Minerals. 33, 131-145 (1997)

7. N. M. B. Mota. Ensaios Avançados de Campo na Argila Porosa Não Saturada de Brasília: Interpretação e Aplicação em Projetos de Fundação. Tese de Doutorado, Publicação G.TD-013A/03, Departamento de Engenharia Civil e Ambiental, Universidade de Brasília, Brasília, DF, 335 p. (2003)

8. O. Johansen. Thermal conductivity of soils (Ph.D. dissertation).Trondheim, Norway (CRREL Draft Translation 637, 1977) (1975)

9. V. Barbosa. A nova era da energia renovável já começou no Brasil. Exame. Fonte: exame.com: http://exame.abril.com.br/economia/noticias/anovaera-da-energia-renovavel-ja-comecou-no-brasil (2016)

10. INPE. CPTEC. INPE. Fonte: http://www.inpe.br/ (2016)

11. S. Lu, T. Ren, Y. Gong, R Horton. An improved model for predicting soil thermal conductivity from water content at room temperature. Soil Science Society of America Journal, 71(1), 8-14. (2007) 